\title{
KINERJA PENGELOLAAN KEUANGAN DAERAH DALAM MENINGKATKAN ANGGARAN PENDAPATAN DAN BELANJA DAERAH KOTA PALEMBANG PROVINSI SUMATERA SELATAN
}

\author{
Krisnawati Arum Kusuma Wardhani \\ Universitas Pamulang \\ email:kriz_krisna@yahoo.com
}

\footnotetext{
Paper Accepted: 22 Juni 2018 Paper Reviewed: 7-15 Juli 2018 Paper Edited: 17-24 Juli 2018 Paper Approved: 25 Juli 2018
}

\begin{abstract}
This research is aimed to find out how the performance of regional financial management of Palembang City in increasing APBD of Palembang City, and how to proportion of revenue and expenditure target of APBD Kota Palembang. The theory used in this study is the concept of performance analysis of regional finances according to Mahmudi (2010), which examines the performance of management of regional keunagan based on the financial performance indicators of regional income and financial performance of Regional Expenditure during the period of 2010 to 2015. In accordance with the focus, Qualitative design, to describe the state of subject / object of research based on facts that appear or as it is (fact finding). Data collection was done by observation, interview, and documentation technique. The result of research shows that the growth of $A P B D$ from the side of regional income shows that there is a trend of revenue increase from $P A D$ post, but in general the balancing fund positions still dominate the regional income, so that the high rate of regional dependency is balanced fund. While from the side of regional expenditure, it is envisaged that every year the Local Government of Palembang City always allocates a larger budget to the indirect spending group. This indicates that the Local Government of Palembang City still allocates more budget for things that are not directly related to the implementation of the program such as personnel expenditure in the form of salaries and allowances regulated in law, interest expenditure, grant expenditure, social assistance expenditure, Results to provinces / districts / municipalities and village governments, unexpected financial aid and shopping expenditures.
\end{abstract}

Keywords: Performance, Management, Regional Finance.

\section{PENDAHULUAN}

Negara Republik Indonesia dengan bentangan wilayah georafis yang sangat luas, membutuhkan suatu sistem dan tata kelola pemerintahan (governance) yang baik. Sistem ini sangat diperlukan setidaknya oleh dua hal: pertama sebagai alat untuk melaksanakan berbagai pelayanan publik di berbagai daerah. Kedua sebagai alat bagi masyarakat setempat untuk dapat berperan serta aktif dalam menentukan arah dan cara mengembangkan taraf hidupnya sendiri selaras dengan peluang dan tantangan yang dihadapi dalam koridor kepentingan-kepentingan nasional.

Untuk tujuan itu banyak yang harus kita lakukan, salah satunya adalah desentralisasi, yaitu pelimpahan tanggung jawab fiskal, politik dan administrasi kebijakan dari Pemerintah Pusat kepada Pemerintah Daerah. Di Indonesia lingkungan legal dan regulasi pokok untuk desentralisasi terangkum dalam tiga undangundang yaitu UU No. 32 Tahun 2004 tentang 
Pemerintahan Daerah yang telah diganti dengan Undang-undang No. 23 Tahun 2014, UU No. 33 Tahun 2004 tentang Perimbangan Keuangan Antara Pemerintah Pusat dan Pemerintahan Daerah, UU No. 28 Tahun 2009 tentang Pajak Daerah dan Retribusi Daerah. Ketiga undangundang tersebut tidak berdiri sendiri secara parsial, tetapi merupakan satu kesatuan untuk mewujudkan daerah otonom yang ekonomis, efisien, efektif, transparan, akuntabel dan responsif secara berkesinambungan. Pada era reformasi sekarang ini, dengan telah dikeluarkannya Undang-undang tadi sangat penting artinya dalam kehidupan sistem ketatanegaraan khususnya sistem Pemerintahan Pusat dan Pemerintahan Daerah, serta sistem hubungan keuangan antara Pemerintah Pusat dan Pemerintahan daerah karena akan membawa perubahan yang mendasar pada upaya peningkatan kesejahteraan seluruh rakyat Indonesia.

Konsekuensi dari pelaksanaan otonomi adalah bahwa daerah harus mampu mengembangkan otonomi daerah secara luas, nyata, dan bertanggungjawab dalam rangka pemberdayaan masyarakat, serta seluruh potensi masyarakat dalam wadah Negara Kesatuan Republik Indonesia. Disisi lain fenomena paling mencolok dari adanya penerapan otonomi daerah adalah ketergantungan pemerintah daerah (Pemda) yang tinggi pada pemerintah pusat. Ketergantungan ini terlihat jelas dari aspek keuangan bahwa pemerintah daerah kehilangan keleluasaan bertindak (local disreaction)( Mardiasmo., 2000; 35). untuk mengambil keputusan-keputusan penting, dan adanya campur tangan pemerintah pusat yang tinggi terhadap pemerintah daerah. Pembangunan di daerah terutama fisik memang cukup pesat, tetapi tingkat ketergantungan fiskal antara daerah terhadap pusat sebagai akibat dari pembangunan juga semakin besar. Selain DKI Jakarta masih banyak daerah-daerah lain sangat tergantung pada sumber dana yang berasal dari pemerintah pusat yang sebagian besar bersifat specifik grants dan sedikit saja yang bersifat block grants. Ketergantungan fiskal terlihat dari relatif rendahnya Pendapatan Asli Daerah (PAD) dan dominannya transfer dari pemerintah pusat (Mardiasmo., 2002;30). Walaupun Undang-Undang telah menggarisbawahi titik berat otonomi pada kabupaten dan kota, namun justru kabupaten dan kota yang mengalami tingkat ketergantungan yang lebih tinggi dibanding provinsi.

Tidak hanya itu setelah otonomi digulirkan Indonesia harus mengalami keterpurukan lagi ketika krisis ekonomi yang melanda Indonesia pada tahun 2007 namun saat itu Indonesia dapat menstabilkan ekonominya. Dua fenomena yang disebutkan sebelumnya menjadi alasan penulis untuk mengangkat judul ini, dengan melihat bagaimana kinerja pemerintah setelah melewati dua fenomena tersebut. Oleh karena itu berkaitan dengan terjadi krisis ekonomi dan hakekat otonomi daerah yang berkenaan dengan pelimpahan wewenang pengambilan keputusan kebijakan, pengelolaan dana publik dan pengaturan kegiatan dalam rangka penyelenggaraan pemerintahan dan pelayanan masyarakat, maka peranan data keuangan daerah sangat dibutuhkan untuk mengidentifikasi sumber-sumber pembiayaan daerah serta jenis dan besar belanja yang harus dikeluarkan agar perencanaan keuangan dapat dilaksanakan secara efektif dan efisien.

Data keuangan daerah yang memberikan gambaran statistik perkembangan anggaran dan realisasi, baik penerimaan maupun pengeluaran dan analisa terhadapnya merupakan informasi yang penting terutama untuk membuat kebijakan dalam pengelolaan keuangan daerah dan melihat kemampuan atau tingkat kemandirian daerah. Berkaitan dengan hal tersebut maka harus dapat dilaksanakan suatu evaluasi terhadap pengelolaan keuangan daerah dan pembiayaan keuangan daerah yang akan sangat menentukan kedudukan suatu pemerintah daerah dalam periode 5 (lima) tahun terakhir. Pengukuran kinerja sangat penting untuk menilai akuntabilitas pemerintah daerah dalam melakukan pengelolaan keuangan daerah. Akuntabilitas bukan sekedar kemampuan menunjukan bagaimana uang publik dibelanjakan, akan tetapi meliputi kemampuan yang menunjukan bahwa uang publik tersebut telah dibelanjakan secara ekonomis, efektif, dan efisien.

Selain tuntutan otonomi yang sangat kuat dari pemerintah daerah, tuntutan akan perimbangan keuangan antara pusat dan daerah yang lebih rasional, proposional, dan nyata tidak hanya sekedar jargon-jargon politik. Demikian pula tuntutan atas pemerintahan yang baik (good governance) dalam arti pemerintahan yang bersih (jujur), terbuka (transparan) dan bertanggungjawab (akuntabel) terhadap masyarakat (Mardiasmo., 2002;40).

Dengan demikian perimbangan keuangan pusat dan daerah yang adil saja belum cukup, masih harus diperlukan pengelolaan atas keuangan daerah, baik yang berasal dari pemerintah pusat maupun yang berasal dari pemerintah daerah sendiri. Kedepan diharapkan adanya pengelolaan keuangan daerah yang baik serta dapat meningkatkan prinsip nilai 
ekonomis, efisiensi dan efektivitas pelayanan publik dan kesejahteraan masyarakat.

Dalam UU No. 23 Tahun 2014 dan UU No. 32 Tahun 2004, secara jelas disebutkan bahwa desentralisasi adalah penyerahan wewenang pemerintah kepada Daerah Otonom dalam kerangka Negara Kesatuan Republik Indonesia (UU No. 23 Tahun 2014 pasal 1, huruf e), Hal ini berarti otonomi menjadi hal yang sangat penting bagi daerah. Otonomi yang diberikan kepada daerah kota dan kabupaten didasarkan pada asas desentralisasi dalam wujud otonomi yang sangat luas, nyata dan bertanggungjawab. Otonomi mencakup pula kewenangan yang penuh dalam menyelenggarakan urusan rumah tangganya, mulai dari tahap perencanaan sampai dengan tahap pelaporan dan evaluasi. Konsekuensi logis dari desentralisasi tersebut, akan ada pelimpahan wewenang dan tanggung jawab dalam menggunakan dana, baik yang berasal dari pemerintah pusat (sesuai dengan urusan yang telah diserahkan) maupun dana yang berasal dari pemerintah daerah sendiri. Untuk pengelolaan dana yang cukup besar ini diperlukan juga peraturan pelaksana yang lebih kongkret dan lebih jelas, seperti Peraturan Pemerintah.

Dalam rangka pertanggungjawaban publik, Pemerintah Daerah harus melakukan optimalisasi anggaran yang dilakukan secara ekonomi, efisiensi, dan efektivitas (value for money) untuk meningkatkan kesejahteraan masyarakat. Pengalaman yang terjadi selama ini menunjukan bahwa manajemen keuangan daerah masih memprihatinkan Anggaran daerah, khususnya pengeluaran daerah belum mampu berperan sebagai insentif dalam mendorong laju pembangunan di daerah. Di sisi lain banyak ditemukan pengalokasian anggaran yang tidak sesuai dengan kebutuhan dan skala prioritas dan kurang mencerminkan aspek ekonomi, efisiensi, dan efektivitas, karena kualitas perencanaan anggaran daerah relatif lemah. Lemahnya perencanaan anggaran juga diikuti dengan ketidakmampuan Pemerintah Daerah untuk meningkatkan penerimaan daerah secara berkesinambungan. Sementara itu pengeluaran daerah terus meningkat, sehingga hal tersebut meningkatkan fiscal gap. Keadaan ini pada akhirnya akan menimbulkan underfinancing atau overfinancing yang pada gilirannya akan mempengaruhi tingkat ekonomi, efisiensi dan efektivitas unit kerja Pemerintah Daerah.

Memasuki era milenium ke-3, masyarakat daerah Kota Palembang memiliki komitmen yang kuat bagi terwujudnya masyarakat madani yang adil dan makmur berasaskan rasa persatuan bangsa. Potensi kekayaan daerah Kota Palembang yang besar merupakan salah satu modal dasar untuk mewujudkan cita-cita di masa depan. Sebagai salah satu Kota yang ada di Indonesia, kota Palembang juga memiliki permasalahan pada pengelolaan keuangan daerah. Hal ini dapat dilihat dari perkembangan APBD Kota Palembang pada tabel 1.1 di bawah ini.

Tabel 1.1 Rasio Dana Perimbangan Terhadap APBD Kota Palembang, 2010 - 2015

\begin{tabular}{|c|c|c|c|c|}
\hline $\begin{array}{c}\text { Tahun } \\
\text { Anggaran }\end{array}$ & $\begin{array}{c}\text { Dana } \\
\text { Perimbangan } \\
(\text { Rp. juta })\end{array}$ & $\begin{array}{c}\text { Pendapatan } \\
(\text { Rp. juta) }\end{array}$ & $\begin{array}{c}\text { Kontribusi } \\
(\boldsymbol{\%})\end{array}$ & $\begin{array}{c}\text { Pertumbuhan Dana } \\
\text { Perimbangan (\%) }\end{array}$ \\
\hline 2010 & $1.177 .289,94$ & $1.625 .168,02$ & 72,44 & - \\
2011 & $1.093 .095,60$ & $1.895 .258,99$ & 57,68 & $-7,15$ \\
2012 & $1.243 .859,63$ & $2.157 .915,95$ & 57,64 & 13,79 \\
2013 & $1.456 .589,12$ & $2.510 .646,25$ & 58,02 & 17,10 \\
2014 & $1.545 .294,77$ & $2.841 .390,98$ & 54,39 & 6,09 \\
$2015^{*}$ & $1.461 .824,83$ & $2.663 .912,37$ & 54,88 & $-5,40$ \\
\hline RATA-RATA & $1.329 .658,98$ & $2.282 .382,09$ & 59,17 & 4,88 \\
\hline
\end{tabular}

Sumber: Bagian Keuangan Kota Palembang, Perhitungan APBD (diolah penulis).

Tabel 1.1 menggambarkan dana perimbangan terhadap pendapatan daerah dan pertumbuhannya dari tahun 2010 sampai dengan tahun 2015, dapat dikemukakan bahwa rasio Dana perimbangan terhadap pendapatan lebih dari $50 \%$. Keadaan ini berarti bahwa lebih dari setengah APBD merupakan kontribusi dari
Dana Perimbangan, dengan pertumbuhan yang semakin meningkat, karena Kota Palembang mempunyai potensi yang cukup besar.

Berdasarkan hal tersebut di atas, serta untuk mengetahui pengelolaan dana desentralisasi yang cukup besar, maka yang menjadi permasalahan dalam penelitian ini 
adalah apakah pengelolaan keuangan daerah Kota Palembang selama tahun anggaran 2010 2015 telah menunjukkan kinerja anggaran (performance budgeting) dengan prinsip value for money yang berorientasi pada kepentingan masyarakat (public oriented.)

\section{PERMASALAHAN PENELITIAN}

Berdasarkan Latar Belakang Penelitian ini, maka permasalahan penelitian dapat dirumuskan sebagai berikut : 1). Bagaimanakah Kinerja pengelolaan keuangan daerah dalam meningkatkan APBD Kota Palembang; 2). Bagaimana proporsi target pendapatan dan belanja APBD Kota Palembang;

\section{METODE PENELITIAN}

Penelitian ini mengunakan Penelitian ini menggunakan desain kualitatif, yang dimaksudkan untuk menjelaskan sifat atau kondisi suatu subyek dalam keadaan apa adanya. Pengumpulan data dilakukan dengan teknik wawancara, telaah dokumen dan observasi. Penentuan informan penelitian dilakukan dengan menggunakan teknik purposive dan snowballing, sedangkan analisis data dilakukan dengan cara reduksi data, penyajian data dan penarikan kesimpulan.

\section{HASIL PENELITIAN DAN PEMBAHASAN}

Penelitian ini menggunakan data sekunder, yaitu data target dan realisasi Anggaran Pendapatan dan Belanja (APBD) terdiri pendapatan dan belanja. Pendapatan terdiri dari Pendapatan Asli Daerah (PAD), Dana Perimbangan, dan Lain-lain Pendapatan yang sah. Belanja terdiri dari belanja langsung dan belanja tidak langsung, yang diambil dari APBD tahun anggaran 2010 sampai tahun 2015 Kota Palembang.

Gambaran mengenai Anggaran Pendapatan dan Belanja Daerah (APBD) selama kurun waktu analisis tahun 2010 sampai tahun 2015 yaitu sisi pendapatan dan belanja baik belanja langsung maupun belanja tidak langsung dapat dilihat pada tabel 1.2 di bawah ini.

Tabel 1.2 Anggaran dan Realisasi Pendapatan, Belanja dan Pembiayaan APBD Kota Palembang, 2010 - 2015 (dalam jutaan rupiah).

\begin{tabular}{|c|c|c|c|c|c|c|}
\hline \multirow{2}{*}{$\begin{array}{c}\text { TAHUN } \\
\text { ANGGARAN }\end{array}$} & \multicolumn{2}{|c|}{ PENDAPATAN DAERAH } & \multicolumn{2}{c|}{ BELANJA DAERAH } & \multicolumn{2}{c|}{ PEMBIAYAAN DAERAH } \\
\cline { 2 - 7 } & ANGGARAN & REALISASI & ANGGARAN & REALISASI & ANGGARAN & REALISASI \\
\hline 2010 & $1.321 .813,60$ & $1.625 .168,03$ & $1.367 .259,21$ & $1.310 .205,39$ & $14.000,00$ & $90.062,47$ \\
\hline 2011 & $1.694 .695,07$ & $1.895 .258,99$ & $1.671 .833,52$ & $1.874 .648,44$ & $22.861,55$ & $147.347,99$ \\
\hline 2012 & $1.995 .636,73$ & $2.157 .915,96$ & $2.009 .879,55$ & $2.112 .638,10$ & $14.242,82$ & $74.501,38$ \\
\hline 2013 & $2.532 .345,00$ & $2.510 .646,26$ & $2.563 .208,97$ & $2.636 .707,56$ & $30.863,97$ & $226.383,10$ \\
\hline 2014 & $2.945 .003,56$ & $2.841 .390,99$ & $2.998 .069,46$ & $2.812 .465,37$ & $53.065,90$ & $26.027,08$ \\
\hline $2015^{*}$ & $3.015 .715,85$ & $2.663 .912,37$ & $3.182 .261,08$ & $2.511 .869,34$ & $166.545,23$ & $160.395,43$ \\
\hline
\end{tabular}

Sumber : BPKAD Kota Palembang.

Tabel 1.2 menggambarkan anggaran dan realisasi pendapatan, belanja dan pembiayaan APBD Kota Palembang mengalami kecendrungan meningkat walaupun pada tahun 2012 dan 2015 terjadi penurunan pada pos pembiayaan daerah. Hal ini jika dibandingkan dengan tahun 2011 pembiayaan daerah sebesar Rp147.347,99 juta sedangkan tahun 2012 turun menjadi $\mathrm{Rp} 74.501,38$ juta namun pada tahun 2013 kembali naik menjadi Rp 226.383,10 juta dan pada tahun 2014 kembali mengalami penurunan sebesar $\mathrm{Rp} 26.027,08$ juta dan kembali meningkat pada tahun 2015 menjadi Rp $160.395,43$ juta.

Gambaran keuangan daerah Kota Palembang selama kurun waktu analisis tahun 2010 - 2015 dari sisi pendapatan yang terdiri dari PAD, Dana Perimbangan serta Lain-Lain Pendapatan Daerah Yang Sah. Tabel 1.3. menggambarkan anggaran pendapatan Kota Palembang dari PAD, Dana Perimbangan serta Lain-Lain Pendapatan Daerah Yang Sah, antara lain anggaran Pendapatan Asli Daerah (PAD) pada tahun 2010 sebesar Rp224.461,34 juta, tahun 2011 meningkat menjadi Rp263.010,45 
juta, tahun 2012 naik menjadi Rp458.533,81 juta, tahun 2013 menjadi Rp509.788,44 juta, tahun 2014 menjadi Rp684.479,59 juta, dan pada tahun 2015 naik menjadi Rp773.614,19 juta dengan rata-rata selama kurun waktu analisis sebesar Rp 485.647,97 juta. Anggaran Dana Perimbangan pada tahun 2010 sebesar Rp954.950,32 juta, tahun 2011 naik menjadi Rp 1.078.538,83 juta, tahun 2012 meningkat menjadi Rp 1.171.996,42 juta, tahun 2013 menjadi Rp 1.474.280,63 juta, tahun 2014 meningkat menjadi Rp 1.575.058,77 dan tahun 2015 menurun menjadi Rp 1.500.048,64 juta dengan rata-rata selama kurun waktu analisis sebesar Rp 1.292.478,94 juta.

Pertumbuhan dan proposisi APBD sisi Pendapatan

Tabel 1.3. Anggaran Pendapatan dan Pertumbuhan APBD Kota Palembang, 2010 - 2015

\begin{tabular}{|c|c|c|c|c|c|c|}
\hline \multirow{3}{*}{$\begin{array}{c}\text { TAHUN } \\
\text { ANGGAR } \\
\text { AN }\end{array}$} & \multicolumn{2}{|c|}{$\begin{array}{l}\text { BELANJA TIDAK } \\
\text { LANGSUNG }\end{array}$} & \multicolumn{2}{|c|}{ BELANJA LANGSUNG } & \multirow[t]{2}{*}{$\begin{array}{c}\text { TOTAL } \\
\text { REALISASI } \\
\text { BELANJA }\end{array}$} & \multirow{2}{*}{\begin{tabular}{|c} 
PERTUMBU \\
HAN APBD \\
$\%$
\end{tabular}} \\
\hline & Anggaran & Realisasi & Anggaran & Realisasi & & \\
\hline & \multicolumn{5}{|c|}{ Rp. Juta } & \\
\hline 2010 & $834.083,06$ & $911.169,24$ & $612.439,89$ & $399.036,14$ & $1.310 .205,39$ & - \\
\hline 2011 & $1.030 .957,15$ & $1.108 .965,98$ & $714.131,28$ & $765.682,45$ & $1.874 .648,43$ & 43,08 \\
\hline 2012 & $1.247 .543,49$ & $1.303 .266,99$ & $863.309,19$ & $809.371,10$ & 2.112.638,10 & 12,70 \\
\hline 2013 & $1.569 .823,20$ & $1.454 .005,74$ & 1.065.632,91 & $1.182 .701,81$ & $2.636 .707,55$ & 24,81 \\
\hline 2014 & $1.667 .709,87$ & $1.528 .679,20$ & $1.415 .947,87$ & $1.283 .786,16$ & $2.812 .465,37$ & 6,67 \\
\hline 2015 & $1.821 .020,71$ & $1.448 .648,10$ & $1.450 .959,69$ & 1.063.221,22 & $2.511 .869,33$ & $-10,69$ \\
\hline Total & $8.171 .137,48$ & $7.754 .735,25$ & $6.122 .420,83$ & $5.503 .798,88$ & $13.258 .534,17$ & - \\
\hline $\begin{array}{l}\text { RATA- } \\
\text { RATA }\end{array}$ & $1.361 .856,25$ & $1.292 .455,88$ & $1.020 .403,47$ & $917.299,81$ & $2.209 .755,70$ & 15,31 \\
\hline $\begin{array}{c}\text { Proporsi } \\
\text { thdp Total } \\
\text { Belanja }\end{array}$ & - & $58,49 \%$ & - & $41,51 \%$ & - & - \\
\hline
\end{tabular}

Sumber : BPKAD Kota Palembang (diolah).

Dari tabel di atas, terungkap bahwa realisasi PAD Kota Palembang dalam kurun waktu analisis, mengalami kenaikan setiap tahunnya, yakni pada tahun 2010 sebesar Rp 214.424,10 juta, tahun 2011 naik menjadi $\mathrm{Rp}$ 369.364,07 juta, tahun 2012 meningkat menjadi Rp 518.858,99 juta, tahun 2013 menjadi Rp 558.704,82 juta, sedangkan tahun 2014 kembali meningkat menjadi Rp 734.218,68 juta, sedangkan pada tahun 2015 mengalami penurunan menjadi Rp 701.544,83 juta.

Selanjutnya realisasi pendapatan dari komponen Dana Perimbangan, pada tahun 2010 mencapai Rp 1.177.289,94 juta, sedangkan tahun 2011 realisasinya turun menjadi $\mathrm{Rp}$ 1.093.095,59 juta, kemudian tahun 2012 realisasinya mengalami kenaikan menjadi $\mathrm{Rp}$ 1.243.859,36 juta, tahun 2013 naik menjadi Rp 1.456.589,11 juta, kemudian tahun 2014 kembali naik menjadi Rp 1.545.294,76 juta sedangkan pada tahun 2015 kembali terjadi penurunan realisasi menjadi Rp 1.461.824,82 juta.

Pada pos Lain-lain Pendapatan daerah yang Sah tahun 2010 realisasinya sebesar Rp 233.453,97 juta, tahun 2011 mengalami kenaikan menjadi Rp 432.799,31 juta, kemudian di tahun 2012 mengalami penurunan menjadi Rp 395.197,60 juta, tahun 2013 naik menjadi Rp 495.352,31 juta, tahun 2014 naik menjadi Rp 561.877,53 juta, sedangkan di tahun 2015, terjadi penurunan menjadi Rp 500.542,71 juta, 
dengan rata-rata pertumbuhan selama kurun waktu analisis sebesar $20,91 \%$.
Pertumbuhan dan Proporsi APBD Sisi Belanja

Tabel 1.4 Anggaran Belanja dan Pertumbuhan APBD Kota Palembang, 2010 - 2015

\begin{tabular}{|c|c|c|c|c|c|c|}
\hline \multirow{3}{*}{$\begin{array}{c}\text { TAHUN } \\
\text { ANGGAR } \\
\text { AN }\end{array}$} & \multicolumn{2}{|c|}{$\begin{array}{l}\text { BELANJA TIDAK } \\
\text { LANGSUNG }\end{array}$} & \multicolumn{2}{|c|}{ BELANJA LANGSUNG } & \multirow{2}{*}{$\begin{array}{c}\text { TOTAL } \\
\text { REALISASI } \\
\text { BELANJA } \\
\end{array}$} & \multirow{2}{*}{$\begin{array}{c}\begin{array}{c}\text { PERTUMBUHAN } \\
\text { APBD }\end{array} \\
\%\end{array}$} \\
\hline & Anggaran & Realisasi & Anggaran & Realisasi & & \\
\hline & \multicolumn{5}{|c|}{ Rp. Juta } & \\
\hline 2010 & $834.083,06$ & $911.169,24$ & $612.439,89$ & $399.036,14$ & $1.310 .205,39$ & - \\
\hline 2011 & $1.030 .957,15$ & $1.108 .965,98$ & $714.131,28$ & $765.682,45$ & $1.874 .648,43$ & 43,08 \\
\hline 2012 & $1.247 .543,49$ & $1.303 .266,99$ & $863.309,19$ & $809.371,10$ & $2.112 .638,10$ & 12,70 \\
\hline 2013 & $1.569 .823,20$ & $1.454 .005,74$ & $1.065 .632,91$ & $1.182 .701,81$ & $2.636 .707,55$ & 24,81 \\
\hline 2014 & $1.667 .709,87$ & $1.528 .679,20$ & $1.415 .947,87$ & $1.283 .786,16$ & $2.812 .465,37$ & 6,67 \\
\hline 2015 & $1.821 .020,71$ & $1.448 .648,10$ & $1.450 .959,69$ & $1.063 .221,22$ & $2.511 .869,33$ & $-10,69$ \\
\hline Total & $8.171 .137,48$ & $7.754 .735,25$ & $6.122 .420,83$ & $5.503 .798,88$ & $13.258 .534,17$ & - \\
\hline $\begin{array}{l}\text { RATA- } \\
\text { RATA }\end{array}$ & $1.361 .856,25$ & $1.292 .455,88$ & $1.020 .403,47$ & $917.299,81$ & $2.209 .755,70$ & 15,31 \\
\hline $\begin{array}{c}\text { Proporsi } \\
\text { thdp Total } \\
\text { Belanja }\end{array}$ & - & $58,49 \%$ & - & $41,51 \%$ & - & - \\
\hline
\end{tabular}

Sumber : BPKAD Kota Palembang (diolah)

Dari tabel di atas, terungkap bahwa realisasi belanja tidak langsung pada APBD Kota Palembang dalam kurun waktu analisis, mengalami fluktuasi setiap tahunnya, yakni pada tahun 2010 sebesar Rp 911.169,24 juta, tahun 2011 naik menjadi Rp 1.108.965,98 juta, tahun 2012 meningkat menjadi Rp 1.303.266,99 juta, tahun 2013 menjadi Rp 1.454.005,74 juta, sedangkan tahun 2014 kembali meningkat menjadi Rp. 1.528.679.20 juta, sedangkan pada tahun 2015 mengalami penurunan menjadi Rp 1.448.648, 10 juta.

Selanjutnya realisasi Belanja Langsung, pada tahun 2010 mencapai Rp 399.036,14 juta, sedangkan tahun 2011 realisasinya naik menjadi Rp 765.682,45 juta, kemudian tahun 2012 realisasinya mengalami kenaikan menjadi Rp 809.371,10 juta, tahun 2013 kembali naik menjadi Rp 1.182.701,81juta, kemudian tahun 2014 naik menjadi $\mathrm{Rp} 1.283 .786,16$ juta sedangkan pada tahun 2015 terjadi penurunan realisasi menjadi Rp 1.063.221,22 juta.

\section{KESIMPULAN DAN SARAN}

\section{KESIMPULAN}

Berdasarkan hasil analisis dan pembahasan yang telah dikemukakan pada bab terdahulu, dapat diambil kesimpulan.
1. Proporsi Anggaran Pendapatan pada APBD Kota Palembang Tahun Anggaran 2010-2015.

Kinerja pengelolaan keuangan daerah dalam meningkatkan APBD dari sisi pendapatan dilakukan dengan Analisis Kinerja Keuangan Pendapatan Daerah yang terlihat dari realisasi pendapatan dan anggaran. Analisis Kinerja Keuangan Pendapatan Daerah dapat dilakukan dengan cara:

1) Analisis Varians Pendapatan Daerah

2) Analisis Pertumbuhan Pendapatan Daerah

3) Analisis Rasio Keuangan Pendapatan Daerah

Dilihat dari pertumbuhan dan kontribusi PAD, Dana Perimbangan dan Lain-lain Pendapatan Daerah Yang Sah terhadap APBD. Memperhatikan data proyeksi pendapatan TA 2010 s.d 2015 tersebut, kenaikan Pendapatan pada tahun 2011 sebesar $28.21 \%$, pada tahun 2012 sebesar $17.76 \%$, pada tahun 2013 sebesar $26.89 \%$, pada tahun 2014 sebesar $16.30 \%$ dan pada tahun 2015 hanya sebesar $2.40 \%$. Secara keseluruhan rata-rata kenaikan pendapatan adalah sebesar $18.31 \%$.

Data APBD Pemerintah Kota Palembang menurut Kelompok Pendapatan yang bersumber dari Perda APBD setiap tahunnya 
menggambarkan bahwa pengganggaran proyeksi pendapatan dari tahun 2010 s.d 2015 selalu menitikberatkan sumber pendapatan dari kelompok dana perimbangan. Sedangkan antara kelompok Pendaparan Asli Daerah (PAD) dan kelompok Lain-Lain Pendapatan Daerah Yang Sah cenderung berimbang.

2. Proporsi Alokasi Anggaran Belanja Pada APBD Kota Palembang Tahun Anggaran 2010 - 2015;

Kinerja pengelolaan keuangan daerah dalam meningkatkan APBD dari sisi belanja dengan Analisis Kinerja Keuangan Belanja Daerah yang antara lain dapat dilakukan dengan cara:

1) Analisis Varians Belanja Daerah

2) Analisis Pertumbuhan Belanja Daerah

3) Analisis Keserasian Belanja Daerah

Sama halnya dengan target Pendapatan, pada sisi belanja Kota Palembang juga selalu mengalami alokasi meningkat. Hal ini dibuktikan dengan adanya perkembangan alokasi anggaran belanja secara siknifikan. Memperhatikan data proyeksi alokasi belanja TA 2010 s.d 2015 tersebut, kenaikan Belanja Daerah pada tahun 2011 adalah sebesar $22.28 \%$, pada tahun 2012 sebesar $20.22 \%$, pada tahun 2013 sebesar $27.53 \%$, pada tahun 2014 sebesar $16.97 \%$ dan pada tahun 2015 hanya sebesar $6.14 \%$. Secara keseluruhan rata-rata kenaikan Belanja Daerah adalah sebesar $18.63 \%$.

Mengacu pada grafik 12 di atas sangat jelas tergambar bahwa setiap tahunnya Pemerintah Daerah Kota Palembang selalu mengalokasikan anggaran belanja yang lebih besar pada kelompok belanja tidak langsung. Selama 6 tahun berturut-turut (tahun 2010 s.d 2015) rata-rata alokasi belanja untuk kelompok belanja tidak langsung adalah sebesar $56.09 \%$ sedangkan rata-rata alokasi belanja untuk kelompok belanja langsung adalah sebesar 43.91\%. Hal ini menunjukkan bahwa Pemerintah Daerah Kota Palembang masih lebih banyak mengalokasikan anggaran belanja untuk hal yang tidak terkait langsung dengan pelaksanaan program seperti belanja pegawai berupa gaji dan tunjangan, belanja bunga, belanja hibah, belanja bantuan sosial, belanja bagi hasil kepada provinsi/kabupaten/kota dan pemerintah desa, belanja bantuan keuangan dan belanja tidak terduga dibandingkan alokasi terhadap belanja langsung seperti belanja barang dan jasa serta belanja modal.

\section{SARAN}

Berdasarkan kesimpulan dalam penelitian ini, maka dapat disarankan pada Pemerintah Kota Palembang sebagai berikut:

1. Dari sisi pendapatan, sebaiknya Pemerintah Kota Palembang hendaknya lebih meningkatkan pendapatan dari komponen PAD, sehingga semakin meningkatkan kemandirian daerah dari sisi pendapatan, dan tidak bergantung pada pemerintah pusat melalui pos dana perimbangan. Mengurangi ketergantungan keuangannya pada pemerintah pusat dengan meningkatkan penerimaan daerah melalui intensifikasi dan ekstensifikasi pemungutan pajak dan retribusi. Selain itu dapat juga mencari sumber-sumber penerimaan lain seperti optimalisasi pemanfaatan atas barang milik daerah yang tidak digunakan untuk tugas dan fungsi penyelenggaraan pemerintah daerah, pola kemitraan, peningkatan penerimaan hasil pengelolaan kekayaan daerah yang dipisahkan. Selain itu dalam Rancangan Peraturan Daerah tentang APBD pada setiap Tahun Anggaran, maka pemerintah kota palembang harus melakukan prognosis target pendapatan secara lebih akurat sesuai potensi sumber pendapatan yang ada di kota palembang berdasarkan peraturan perundang-undangan serta harus memperhatikan tingkat rasionalitas bagian laba atas penyertaan modal kepada Badan Usaha Milik Daerah (BUMD).

2. Dari sisi belanja, agar dalam penyusunan APBD dalam kelompok belanja pemerintah kota palembang hendaknya lebih mengefektifkan mekanisme perencanaan dari bawah (bottom up planning), sehingga dapat menjaring aspirasi masyarakat dan alokasi belanja yang lebih berorientasi pada kepentingan publik, melalui penyusunan standar analisa belanja untuk mencapai tingkat kinerja pengeluaran yang ekonomis, efektif, efisien serta perlu ditiingkatkan proporsi belanja pembangunan yang lebih besar, sehingga social welfare dapat tercapai. Selain itu dalam penganggaran belanja sebaiknya tidak adanya duplikasi penganggaran dan telah memperhatikan prinsip 
rasionalitas, transparansi kewajaran serta kepatutan.

\section{DAFTAR PUSTAKA}

Arikunto, Suharsimi, 1998, Prosedur Penelitian (Suatu Pendekatan Praktek), Rineka Cipta, Jakarta.

Bastian, Indra. 2009. Akuntansi Sektor Publik di Indonesia. Yogyakarta: BPFEYogyakarta.

Devas, Nick Brian Binder, Anne Booth, Kenneth Davey and Roy Kelly, 1989, Keuangan Pemerintah Daerah di Indonesia", (terjemahan oleh Masri Maris), UI-Press, Jakarta.

Insukindro, Mardiasmo, Wahyu Widayat, Wihana Kirana Jaya, BM Purwanto, Abdul Halim, John Suprihanto, dan A Budi Pornomo, 1994, "Peran dan Pengelolaan Keuangan Daerah dalam Uasaha Meningkatkan PAD”, Laporan Penelitian, Kerja sama Departemen Keuangan RI dengan Fakultas Ekonomi UGM, Yogyakarta, (tidak dipublikasikan).

Josef Riwu Kaho. 1998. Prospek Otonomi Daerah di Negara Indonesia (Identifikasi Beberapa Faktor yang Mempengaruhi Penyelenggaraannya). Jakarta: Rajawali Press.

Kuncoro, M., 1995, "Desentralisasi Fiscal di Indonesia, Dilema Otonomi dan Ketergantungan", Prisma, No.4, 3 -17.

Mahmudi. 2010. Manajemen Kinerja Sektor Publik Edisi Kedua. Yogyakarta: UPP STIM YKPN.

Mardiasmo., 2000, "Paradigma Baru Pengelolaan Keuangan Daerah Untuk Menyongsong Pelaksanaan Otonomi Daerah 2001", makalah disampaikan pada Seminar HIMMEP, Universitas Gadjah Mada Yogyakarta.

-., 2001, "Perencanaan Keuangan Publik Sebagai Suatu Tuntutan dalam Pelaksanaan Pemerintahan Daerah yang Bersih dan Berwibawa", Diskusi Panel Nasional, Jakarta.

Mardiasmo. 2002. Otonomi dan Manajemen Keuangan Daerah. Yogyakarta: Penerbit Andhi.

Josef Riwu Kaho. 1998. Prospek Otonomi Daerah di Negara Indonesia (Identifikasi Beberapa Faktor yang Mempengaruhi Penyelenggaraannya). Jakarta: Rajawali Press. Mardiasmo. 2002. Otonomi dan Manajemen Keuangan Daerah. Yogyakarta: Penerbit Andhi.
Mudrajad Kuncoro. 1995. "Desentralisasi Fiskal di Indonesia: Dilema Otonomi dan Ketergantungan". Prisma, No. 4, 3-17. Mudrajad Kuncoro. 2004. Otonomi dan Pembangunan Daerah. Lakant: Erlangga.

.........., 2000, "Paradigma Baru Pengelolaan Keuangan Daerah Untuk Menyongsong Pelaksanaan Otonomi Daerah 2001", makalah disampaikan pada Seminar HIMMEP, Universitas Gadjah Mada Yogyakarta.

-----------., 2001, "Perencanaan Keuangan Publik Sebagai Suatu Tuntutan dalam Pelaksanaan Pemerintahan Daerah yang Bersih dan Berwibawa", Diskusi Panel Nasional, Jakarta.

------------., 2001, "Perencanaan Keuangan Publik Sebagai Suatu Tuntutan dalam Pelaksanaan Pemerintahan Daerah", makalah Diskusi Panel Nasional, Jakarta. 2004. Otonomi dan Pembangunan Daerah. Lakant: Erlangga.

Miller, Stephen M., Russek, Frank S., 1997, "Fiscal Structures and Economic Growth at The State and Local Level", Public Finance Review, Vol..XIV No. 25, 213 237.

Nazir, Moh, 1988, Metode Penelitian, Ghalia Indonesia, Jakarta.

Nasution, S, 2002, Metode Reseach, PT. Bumi Aksara, Jakarta.

Odedokun, MO., 1996, "Financial Policy and Efficiency of Resource Utilization in Developing Countries", Growth and Change, Vol. 27, 269-297.

Sugiyono, 1999. Penelitian Bisnis, Bandung : Alfabeta. 2007. Memahami Penelitian Kualitatif, Bandung : Alfabeta.

Shah, Anwar., 1994, "The Reform of Intergovermental Relation On Developing and emerging Market Economics" Policy and Research Series, No. 23, World Bank, Washington D.C.

Widodo,ST, 1990, Indikator Ekonomi Dasar Perhitungan Perekonomian Indonesia, Kanisius, Yogyakarta.

World Bank., 1998, Public Expenditure Management Handbook, Washinton D.C

\section{Peraturan Perundang-undangan}

Undang-undang Republik Indonesia Nomor 32 Tahun 2004 tentang Pemerintahan Daerah.

Undang-Undang Nomor 33 Tahun 2004 tentang Perimbangan Keuangan antara Pemerintah Pusat dan Daerah 
Undang-Undang Republik Indonesia Nomor 23 Tahun 2014 tentang Pemerintahan Daerah Undang-undang Nomor 28 Tahun 2009 tentang Pajak Daerah dan Retribusi Daerah.

Peraturan Pemerintah Nomor 58 Tahun 2005 tentang Pengelolaan Keuangan Daerah

Peraturan Pemerintah Nomor 69 Tahun 2010 tentang Tata Cara Pemberian dan Pemanfaatan Insentif Pemungutan Pajak Daerah dan Retribusi Daerah

Peraturan Pemerintah Nomor 71 Tahun 2010 tentang Standar Akuntansi Pemerintahan;

Permendagri Nomor 13 Tahun 2006 tentang Pedoman Pengelolaan Keuangan Daerah sebagaimana telah diubah beberapa kali terakhir Permendagri Nomor 21 Tahun 2011 tentang Perubahan Kedua atas
Peraturan Menteri Dalam Negeri Nomor 13 Tahun 2006.

Peraturan Daerah Kota Palembang tentang APBD Kota Palembang Tahun 2010.

Peraturan Daerah Kota Palembang tentang APBD Kota Palembang Tahun 2011.

Peraturan Daerah Kota Palembang tentang APBD Kota Palembang Tahun 2012.

Peraturan Daerah Kota Palembang tentang APBD Kota Palembang Tahun 2013.

Peraturan Daerah Kota Palembang tentang APBD Kota Palembang Tahun 2014.

Peraturan Daerah Kota Palembang tentang APBD Kota Palembang Tahun 2015.

Kota Palembang Dalam Angka, BPS Kota Palembang. 